\title{
Long-Term Survival after Radical Resection for Pancreatic Head and Ampullary Cancer: A Potential Role for the EGF-R
}

\author{
H.G.Smeenk ${ }^{a} \quad$ J. Erdmann ${ }^{a} \quad$ H. van Dekken ${ }^{b} \quad$ R. van Marion ${ }^{b} \quad$ W.C.J. Hop ${ }^{c}$ \\ J. Jeekel ${ }^{a}$ C.H.J. van Eijck ${ }^{a}$
}

Departments of a Surgery, ${ }^{b}$ Pathology and ' Epidemiology and Biostatistics, Erasmus Medical Center, Rotterdam, The Netherlands

\section{Key Words}

Pancreatic head cancer - Ampullary cancer - Survival, ampullary/pancreatic head cancers - Prognostic factors • Epithelial growth factor receptor $\cdot \mathrm{C}$-myc $\cdot$ Tissue microarray

\begin{abstract}
Background/Aim: Pancreatic cancer has a dismal prognosis. Ampullary cancer (defined as cancer of the ampulla of Vater or the distal common bile duct) has a better prognosis and is thought to be a biologically different tumor. The aim of this study was to find factors that could predict survival after radical ( $\mathrm{R}-0$ ) resection for pancreatic head and ampullary cancers. Methods: We analyzed clinical and pathological data from 93 patients who underwent a true R-0 resection for pancreatic head or ampullary cancer. Furthermore, we performed a tissue microarray protein expression analysis for several growth factor receptors and oncogenes: HER-2, EGF-R, ER, PR, C-myc, p53, p16, RB-1, and chromogranin A as a neuroendocrine differentiation marker. Results: Median survival (14 vs. 42 months) and time to recurrence (16 vs. 42 months) were significantly longer for ampullary than for pancreatic head cancers. Preoperative pain, perineural invasion, lymph node metastasis, and tumor differentiation grade are indicators of a poor survival. No differences in protein expression were found between groups, except for
\end{abstract}

EGF-R which was expressed more in pancreatic head cancers $(p=0.026)$. Conclusions: Outcomes for ampullary cancers are better than for pancreatic head cancers. This different biological behavior can possibly be explained by differences in EGF-R expression.

Copyright $\odot 2007$ S. Karger AG, Basel

\section{Introduction}

Of all gastrointestinal malignancies, pancreatic cancer has the poorest prognosis, with a 5-year survival of less than $5 \%[1,2]$. Men are more frequently affected by this disease than women (relative risk 1.5) [2]. Ampullary cancers, however, carry a better prognosis [3]. This evident difference may be due to earlier clinical presentation or different biological behavior. Curative resection offers the only chance of cure, but is possible in only $10 \%$ of the patients [4]. Adjuvant chemotherapy and chemoradiotherapy after curative resection are of limited value [5]. Even after a macroscopically radical resection (R-0), distant micrometastases probably already exist [6], and tumor cells are often observed at one or more edges of the resected specimen (R-1) [7, 8]. Reported relevant prognostic variables for survival after resection are: tumor size, lymph node metastasis, histological differentiation, and resection status [9-12]. Most studies include R-0 as 
well as nonradical (R-1/R-2) resections. To eliminate the apparent effect of R-1 status on (local) recurrence and survival, it would be interesting to evaluate true R-0 resections only.

The aim of this study was to determine clinical, histological, and molecular factors that could predict recurrence and survival after R-0 resection. Special focus is on the differences between ampullary (defined as cancer of the ampulla of Vater or distal common bile duct) and pancreatic head cancers. Additionally a tissue microarray (TMA) analysis of resected tumors (R-0) was added in order to search for relevant molecular factors [13, 14]. For immunohistochemical staining, we selected common antibodies raised against proteins that are frequently expressed in (pancreatic and ampullary) cancers such as: retinoblastoma (RB-1) [15, 16], p16 [17], C-myc [18], and p53 [17]. Potential targets for therapy: HER-2 [19] and epithelial growth factor receptor (EGF-R) [20]. Potential markers for a male/female difference: estrogen receptor (ER) and progesterone receptor (PR) [21]. Chromogranin $A$ was used as a neuroendocrine differentiation marker.

\section{Materials and Methods}

From a consecutive series of 176 resections for pancreatic head and ampullary adenocarcinomas, specimens were revisited. For the purpose of this study we defined ampullary cancer as cancer of ampulla of Vater and distal common bile duct. Duodenal tumors were not included. Pancreatic cancers adjacent or close to the ampulla were classified as pancreatic head cancer. R-0 was defined as absence of macroscopic and microscopic residual tumor $>1 \mathrm{~mm}$ from the margin of the resection specimen. Even if there were lymph node metastases restricted to the resected area, the resection was considered R- 0 . Seventy patients had an R-1 and 6 patients an R-2 resection. In 7 cases the pathologist was not able to define whether a true R-0 resection was performed. Therefore, 93 patients were evaluated in this study.

One pathologist reviewed all specimens of R-0 resected tumors. Histological differentiation, tumor size (T), location and extent, as well as vasoinvasive growth (small blood vessels), perineural invasive growth, and lymph node metastasis $(\mathrm{N})$ were assessed. Staging was performed according to the UICC classification, 2002 [22].

Preoperative data, including age, gender, weight loss, pain (back pain and pain in the epigastric region), jaundice, and diabetes mellitus, were obtained from the clinical records.

\section{Preoperative Staging and Surgical Techniques}

All patients underwent conventional ultrasonography and/or computed tomographic scanning. Most patients (76\%) underwent endoscopic retrograde cholangiopancreatography and subsequent preoperative biliary drainage using endoprostheses. After excluding extraregional and distant metastases, an estimation of the resectability was made by judging the involvement of com- mon hepatic artery and superior mesenteric vein and portal vein. Dissection of the pancreas was to the left of superior mesenteric vein/portal vein. Histological examination of the frozen section of the remaining pancreatic surface was performed. In case of a standard Whipple (SW) resection, one third of the stomach was also resected. Only tumors without macroscopic infiltration of the postpyloric duodenum and in absence of positive lymph nodes along the pylorus were treated by a pylorus-preserving pancreaticoduodenectomy (PPPD). Lymph nodes were dissected on the right-hand side of superior mesenteric vein/superior mesenteric artery up to the celiac trunk and in the hepatoduodenal ligament along the common hepatic artery. Perioperative data included type of operation performed (PPPD or SW), blood loss (ml), and transfusions (units). Postoperative data included complications, hospital stay, and adjuvant therapy (5-FU and radiotherapy).

\section{Tissue Microarray}

We identified 75 patients for whom paraffin blocks were available. In all other cases paraffin blocks were either lost or insufficient. The TMA was constructed as described by Kononen et al. [13]. For each carcinoma, we prepared three tissue cores of 0.6 $\mathrm{mm}$ in diameter from the paraffin tissue block to ensure adequate representation of the neoplastic cells. The tissue cores from each carcinoma were then mounted in linear arrays in a paraffin TMA block. Tissue cores from various organs (pancreas, duodenum, and gallbladder) were used as controls, for orientation purposes, and to estimate background labeling for each of the immunohistochemical markers. Immunohistochemistry labeling was performed according to standard protocols. In brief, 4- $\mu \mathrm{m}$ sections for each TMA were transferred to StarFrost ${ }^{\circledR}$ slides (Starfrost, Berlin, Germany), and immunostaining was performed using the UltraVision Large Volume Detection System Anti-Polyvalent, HRP (Lab Vision, Fremont, Calif., USA) after deparaffinization. Microwave $(700 \mathrm{~W})$ pretreatment was performed for $15 \mathrm{~min}$ using citrate buffer (100 mM citric monohydrate, $\mathrm{pH}$ 6.0). Antibodies (clone) used for immunostaining were ER- $\alpha$ (1D5), PR (PgR636), p16 (E6H4), p53 (DO-7), RB-1 (RB-1), EGF-R (H11), and HER2 (C-erB-2) (DAKO, Glostrup, Denmark); chromogranin A (LK2H10) (Biogenex, San Ramon, Calif., USA), and C-myc (9E10) (Santa Cruz Biotechnology, Santa Cruz, Calif., USA).

\section{TMA Scoring Strategy}

A pathologist and an experienced analyst examined the TMA slides for each immunohistochemical marker with a multiobserver microscope. Both observers were blinded to the type of cancer and its location on the slide. Only moderate or strong labeling was scored as positive. Weak or 'blush' labeling was ignored. A twotiered scheme (positive or negative) was used for scoring the TMA. A proportion exceeding $1 \%$ of positive cells was regarded as protein overexpression. A negative or positive score for each carcinoma was determined after examining the three tissue cores. Focal and diffuse positive scores were combined for the sake of statistical analysis.

\section{Statistics}

Survival analysis consisted of overall survival and time to recurrence. Curves were calculated by the Kaplan-Meier method, followed by log-rank tests. Factors, which showed to be significant in the univariate analysis, were entered into a multivariate Cox proportional hazards model to evaluate their independent prog- 
Table 1. Group comparisons

\begin{tabular}{|c|c|c|c|c|}
\hline & \multicolumn{3}{|c|}{ Factor positive (\%) } & \multirow{2}{*}{$\begin{array}{l}\mathrm{p} \text { (Fisher's } \\
\text { exact } \\
\text { t test) }\end{array}$} \\
\hline & $\begin{array}{l}\text { head } \\
(n=56)\end{array}$ & $\begin{array}{l}\text { ampullary } \\
(\mathrm{n}=37)\end{array}$ & $\begin{array}{l}\text { total } \\
(\mathrm{n}=93)\end{array}$ & \\
\hline \multicolumn{5}{|l|}{ Preoperative factors } \\
\hline Male sex & $37(66)$ & $19(51)$ & 37 (39) & 0.191 \\
\hline Age, years & 63 & 63 & 63 & 0.993 \\
\hline Pain & $31(55)$ & $20(56)$ & $51(55)$ & 1 \\
\hline Jaundice & $49(88)$ & $30(83)$ & $79(86)$ & 0.76 \\
\hline Pruritus & $13(23)$ & $15(44)$ & $28(31)$ & 0.059 \\
\hline Weight loss & $45(80)$ & $28(78)$ & $73(79)$ & 0.796 \\
\hline$>5 \mathrm{~kg}$ & $23(51)$ & $18(64)$ & $41(56)$ & 0.335 \\
\hline Obstruction & $5(9)$ & $5(14)$ & $10(11)$ & 0.505 \\
\hline Diabetes & $10(18)$ & $8(22)$ & $18(20)$ & 0.603 \\
\hline Endoprosthesis & $44(79)$ & $27(71)$ & $71(78)$ & 1 \\
\hline \multicolumn{5}{|l|}{ Perioperative factors } \\
\hline PPPD & $28(50)$ & $18(49)$ & $46(50)$ & 1 \\
\hline PV resection & $1(2)$ & 0 & $1(1)$ & 1 \\
\hline SMA resection & 0 & $1(3)$ & $1(1)$ & 0.398 \\
\hline Blood loss, ml & 2,700 & 1,950 & 2,400 & $0.028^{\mathrm{a}}$ \\
\hline >1 liter & $5(9)$ & $6(18)$ & $11(13)$ & 0.324 \\
\hline Transfusions, $\mathrm{U}$ & 2.4 & 1.5 & 1.2 & $0.038^{\mathrm{a}}$ \\
\hline Transfused patients & $22(41)$ & $7(21)$ & $29(33)$ & 0.064 \\
\hline Complications & $24(44)$ & $20(54)$ & $44(48)$ & 0.396 \\
\hline \multicolumn{3}{|c|}{ Leakage pancreaticojejunostomy } & $5(5)$ & \\
\hline \multicolumn{2}{|c|}{ Pancreatic fistula } & & $6(6)$ & \\
\hline \multicolumn{2}{|c|}{ Leakage biliary anastomosis } & & $1(1)$ & \\
\hline \multicolumn{2}{|l|}{ Abdominal abscess } & & $11(12)$ & \\
\hline \multicolumn{2}{|l|}{ Minor } & & $17(18)$ & \\
\hline \multicolumn{2}{|l|}{ Mortality } & & $2(2)$ & \\
\hline Hospitalization, months & 28 & 21 & & $0.048^{\mathrm{a}}$ \\
\hline Radiation/5-Fu & $19(34)$ & $9(24)$ & $28(30)$ & 0.363 \\
\hline \multicolumn{5}{|l|}{ Pathological factors } \\
\hline $\mathrm{T} 1$ & $7(12)$ & $8(22)$ & & not tested \\
\hline \multirow{2}{*}{$\begin{array}{l}\text { T2 } \\
\text { T3 }\end{array}$} & $15(27)$ & $16(43)$ & & not tested \\
\hline & $34(61)$ & $13(35)$ & & not tested \\
\hline Diameter $<2 \mathrm{~cm}$ & $23(41)$ & $28(76)$ & $51(55)$ & 0.001 \\
\hline $\mathrm{N}$ & $29(52)$ & $26(70)$ & $55(59.1)$ & 0.088 \\
\hline M & 0 & 0 & 0 & \\
\hline G1 & $6(11)$ & $7(19)$ & & $0.509^{\mathrm{b}}$ \\
\hline $\begin{array}{l}\text { G2 } \\
\text { G3 }\end{array}$ & $43(79)$ & $25(68)$ & & \\
\hline G3 & $7(12)$ & $5(13)$ & & \\
\hline $\mathrm{R}-0$ resection & $56(100)$ & $37(100)$ & & \\
\hline \multirow{2}{*}{$\begin{array}{l}\text { Perineural invasion } \\
\text { Vasoinvasive }\end{array}$} & $31(55)$ & $7(19)$ & $38(41)$ & 0.001 \\
\hline & $11(20)$ & $5(14)$ & $16(17)$ & 0.579 \\
\hline Survival & & & & \\
\hline Recurrences & $41(73)$ & $26(70)$ & $67(72)$ & 0.816 \\
\hline Local & $7(18)$ & $6(26)$ & & $0.497^{\mathrm{b}}$ \\
\hline Distant & $18(46)$ & $8(35)$ & & \\
\hline Both & $12(31)$ & $9(39)$ & & \\
\hline Deaths & $51(91)$ & $28(76)$ & $79(85)$ & 0.073 \\
\hline Median survival, months & 142 & 42 & & $0.001^{\mathrm{c}}$ \\
\hline Median time to & & & & \\
\hline recurrence, months & 16 & 34 & & $0.024^{\mathrm{c}}$ \\
\hline
\end{tabular}

\begin{tabular}{|c|c|c|c|c|}
\hline & \multicolumn{3}{|c|}{ Factor positive (\%) } & \multirow{2}{*}{$\begin{array}{l}\mathrm{p} \text { (Fisher's } \\
\text { exact } \\
\mathrm{t} \text { test) }\end{array}$} \\
\hline & $\begin{array}{l}\text { head } \\
(\mathrm{n}=56)\end{array}$ & $\begin{array}{l}\text { ampullary } \\
(\mathrm{n}=37)\end{array}$ & $\begin{array}{l}\text { total } \\
(\mathrm{n}=93)\end{array}$ & \\
\hline \multicolumn{5}{|l|}{ Tissue microarray } \\
\hline ER- $\alpha$ & $0(0)$ & $1(3.7)$ & $1(1)$ & 0.365 \\
\hline PR & $5(11)$ & $1(3.7)$ & $6(80)$ & 0.406 \\
\hline p16 & $10(21)$ & $9(33)$ & $19(25)$ & 0.28 \\
\hline p53 & $9(20)$ & $5(19)$ & $14(19)$ & 1 \\
\hline RB-1 & $28(62)$ & $20(77)$ & $48(64)$ & 0.293 \\
\hline C-myc & $19(41)$ & $16(59)$ & $35(47)$ & 0.154 \\
\hline Chromogranin A & $10(22)$ & $6(22)$ & $16(21)$ & 1 \\
\hline EGF-R & $11(24)$ & $1(3.7)$ & $12(16)$ & 0.026 \\
\hline HER-2 & $4(9)$ & $3(11)$ & $7(9)$ & 1 \\
\hline
\end{tabular}

PPPD = Pylorus-preserving pancreaticoduodenectomy; PV = portal vein; SMA = superior mesenteric artery; $\mathrm{T}$ = primary tumor; $\mathrm{N}=$ positive lymph nodes; $\mathrm{M}=$ metastasis; $\mathrm{G}=$ differentiation grade.

${ }^{\mathrm{a}} \mathrm{t}$ test; ${ }^{\mathrm{b}}$ chi-square for $3 \times 2$ tables; ${ }^{\mathrm{c}} \log$-rank test.

nostic value by backward elimination. To determine whether factors differed between patients with ampullary versus pancreatic head carcinomas, appropriate interaction terms were used. p (two-sided) $<0.05$ was considered statistically significant. All calculations were performed using SPSS version 13.0 (SPSS, Chicago, Ill., USA).

\section{Results}

\section{Survival}

The follow-up period was more than 10 (median 12) years. Median survival and time to recurrence were significantly longer for ampullary than for pancreatic head cancers (14 and 42 months, $\mathrm{p}=0.001$, and 16 and 34 months, $\mathrm{p}=0.024$, respectively; table 1 ). Survival curves are shown in figure 1 . There were no differences between groups with regard to site of recurrence $(p=0.497)$.

\section{Preoperative Factors}

No differences in preoperative factors were observed between both groups. Survival was better for women than for men in the pancreatic head cancer group, but not in the ampullary cancer group. Preoperative abdominal and back pain significantly influenced survival and time to recurrence for both groups. Jaundice was a predictor of survival and time to recurrence in ampullary cancers. Weight loss and diabetes mellitus did not influence survival (tables 1,2 ). 
Table 2. Univariate analysis

\begin{tabular}{|c|c|c|c|c|c|c|c|}
\hline \multirow[t]{2}{*}{ Factor positive } & \multirow{2}{*}{$\begin{array}{l}\text { Direction } \\
\text { of effect }\end{array}$} & \multicolumn{3}{|c|}{ Relation to survival } & \multicolumn{3}{|c|}{ Time to recurrence } \\
\hline & & $\begin{array}{l}\text { head } \\
(n=56)\end{array}$ & $\begin{array}{l}\text { ampullary } \\
(\mathrm{n}=37)\end{array}$ & $\begin{array}{l}\text { pooled }^{\mathrm{a}} \\
(\mathrm{n}=93)\end{array}$ & $\begin{array}{l}\text { head } \\
(n=56)\end{array}$ & $\begin{array}{l}\text { ampullary } \\
(\mathrm{n}=37)\end{array}$ & $\begin{array}{l}\text { pooled }^{\mathrm{a}} \\
(\mathrm{n}=93)\end{array}$ \\
\hline Male sex & - & 0.028 & 0.688 & 0.046 & 0.072 & 0.614 & 0.086 \\
\hline Pain & - & 0.018 & 0.001 & 0.000 & 0.006 & 0.000 & 0.000 \\
\hline Jaundice & + & 0.364 & 0.029 & 0.044 & 0.773 & 0.017 & 0.097 \\
\hline $\mathrm{N}$ & - & 0.064 & 0.013 & 0.004 & 0.016 & 0.006 & 0.000 \\
\hline G & - & 0.034 & 0.624 & 0.012 & 0.046 & 0.384 & 0.012 \\
\hline Perineural invasion & - & 0.273 & 0.001 & 0.025 & 0.053 & 0.000 & 0.001 \\
\hline C-myc & + & 0.034 & 0.968 & 0.078 & 0.015 & 0.858 & 0.038 \\
\hline EGF-R & - & 0.084 & not tested & 0.080 & 0.037 & not tested & 0.042 \\
\hline
\end{tabular}

Pain = Preoperative back pain and abdominal pain; $\mathrm{N}=$ positive lymph nodes; $\mathrm{G}=$ differentiation grade. a Test for trend.

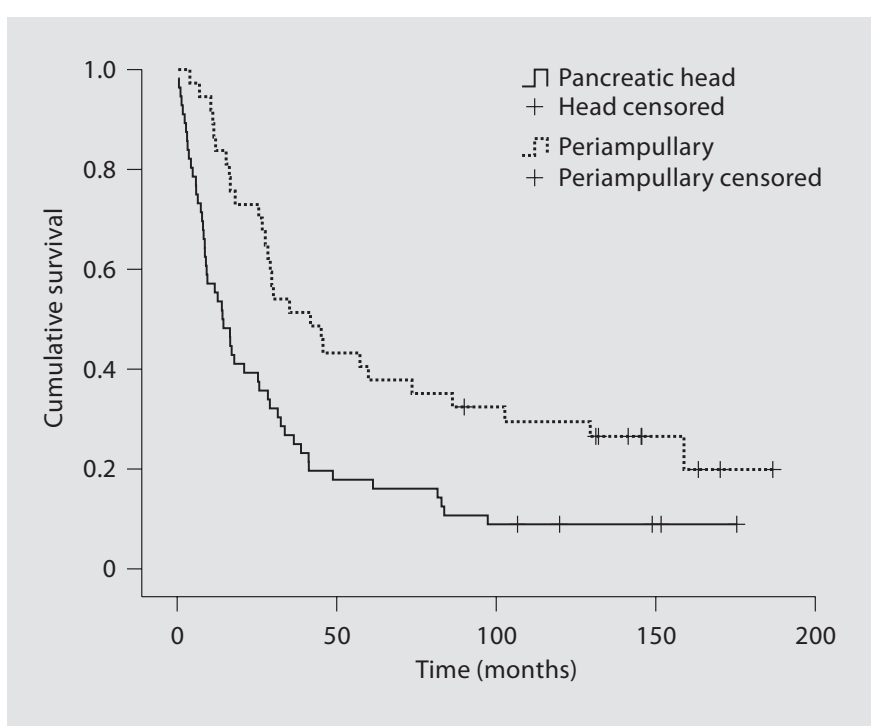

Fig. 1. Kaplan-Meier survival curves for ampullary and pancreatic head cancers $(\mathrm{p}=0.001, \log$-rank test).

\begin{tabular}{|c|c|c|c|c|c|c|c|c|}
\hline \multirow[t]{2}{*}{ At risk } & \multicolumn{8}{|c|}{ Time (months) } \\
\hline & 12 & 24 & 36 & 48 & 60 & 72 & 84 & 120 \\
\hline $\mathrm{ad}$ & 31 & 22 & 15 & 11 & 10 & 10 & 5 & 3 \\
\hline Ampullary & 32 & 27 & 19 & 16 & 14 & 13 & 13 & 10 \\
\hline
\end{tabular}

\section{Perioperative Findings}

The surgical technique used (PPPD vs. SW) did not correlate with survival $(p=1.000)$. Blood losses were higher and blood transfusions (units) more often required in the pancreatic head cancer group $(\mathrm{p}=0.028$ and
0.038). Hospitalization was longer for pancreatic head cancers ( $p=0.048)$. However, these factors did not influence survival (tables 1,2).

\section{Mortality and Morbidity}

Two patients (2\%) died postoperatively because of aspiration pneumonia and sepsis. These patients remained in our analysis because of the intent-to-treat principle. Postoperative complications occurred in 44 cases (48\%). In 5 patients (5\%), leakage of the pancreaticojejunostomy was seen, defined as the presence of amylase in drainage or abdominal fluid ( $>3 \times$ serum concentration). Six patients developed a pancreaticocutaneous fistula. Leakage of the biliary anastomosis occurred in 1 patient. Eleven patients (12\%) had an intra-abdominal abscess. Minor complications were found in 17 patients (18\%). Complications did not influence survival or time to recurrence (tables 1,2 ).

\section{Adjuvant Therapy}

Adjuvant therapy (5-FU and radiotherapy) was given to 28 patients, distributed evenly between both groups $(\mathrm{p}=0.363$; table 1). Survival data are omitted because of bias. These patients participated in a trial, in which we compared the effects of chemoradiation with those of surgery alone [3].

\section{Pathological Factors}

Pancreatic head tumors were larger $(\mathrm{p}=0.001)$ than ampullary tumors. Perineural invasion was also significantly more often observed in this group $(\mathrm{p}=0.001)$.

The strongest negative histological factor for survival and time to recurrence was lymph node involvement in 


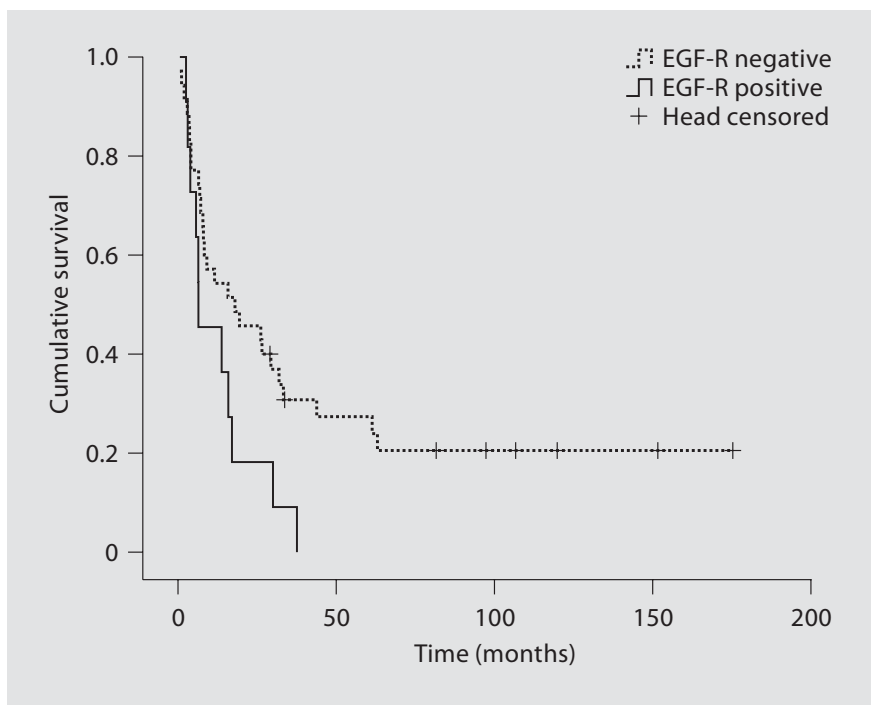

Fig. 2. Kaplan-Meier curves for EGF-R expression in pancreatic head cancers, time to recurrence ( $\mathrm{p}=0.037$, log-rank test).

\begin{tabular}{llrrrrrrrr}
\hline At risk & & \multicolumn{1}{c}{ Time (months) } & & & & \\
\cline { 2 - 9 } & & 12 & 24 & 36 & 48 & 60 & 72 & 84 & 120 \\
\hline Positive & $(\mathrm{n}=11)$ & 5 & 2 & 1 & 0 & & & & \\
Negative & $(\mathrm{n}=35)$ & 19 & 16 & 9 & 8 & 8 & 6 & 4 & 2 \\
\hline
\end{tabular}

the resected specimen. Tumor diameter as well as extent of the tumor did not influence survival. Histological grading was correlated with survival and time to recurrence for pancreatic head cancers. Invasive growth into intrapancreatic perineural tissue significantly influenced survival $(p=0.001)$ and time to recurrence $(p=0.000)$ in ampullary cancers. Tumor invasion of small surrounding blood vessels was not correlated with survival (tables 1,2).

\section{Tissue Microarray}

The overall failure rate secondary to lack of interpretable neoplastic tissue was 3\%. In all other cases in whom cores were without malignant glands, interpretation of the labeling pattern was possible with the remaining tissue cores from the same carcinoma. Although histologically very similar, adenocarcinomas of the ampullary region are thought to be biologically different from pancreatic ductal adenocarcinomas. However, for most tested proteins, the labeling was not significantly different between both groups. Interestingly, EGF-R is expressed more frequently in pancreatic head than in ampullary cancers $(p=0.026)$. For pancreatic head cancers, EGF-R

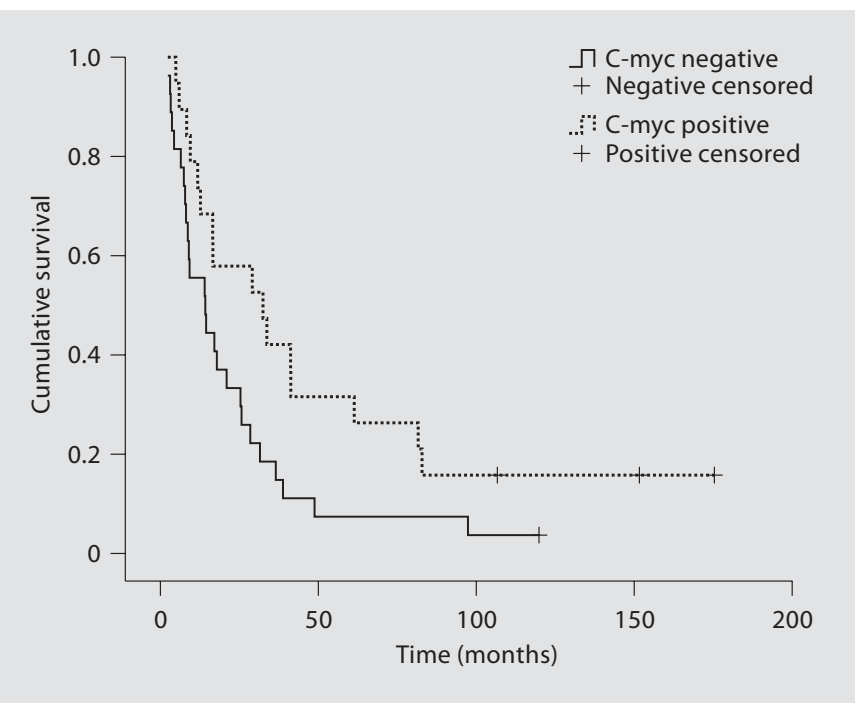

Fig. 3. Kaplan-Meier survival curves for C-myc expression in pancreatic head cancers $(\mathrm{p}=0.034$, log-rank test).

\begin{tabular}{|c|c|c|c|c|c|c|c|c|c|}
\hline \multirow[t]{2}{*}{ At risk } & & \multicolumn{8}{|c|}{ Time (months) } \\
\hline & & 12 & 24 & 36 & 48 & 60 & 72 & 84 & 120 \\
\hline Positive & $(\mathrm{n}=19)$ & 14 & 10 & 7 & 5 & 5 & 4 & 2 & 2 \\
\hline Negative & $(\mathrm{n}=27)$ & 15 & 9 & 5 & 3 & 2 & 2 & 2 & 0 \\
\hline
\end{tabular}

overexpression is an indicator for a shorter time to recurrence $(\mathrm{p}=0.037$; fig. 2$)$. A trend was observed towards a poor survival (median 14 vs. 25 months; $\mathrm{p}=0.084$ ). Furthermore, no long-term survivors were observed in the EGF-R-positive group. C-myc overexpression is correlated with improved survival ( $p=0.034$; fig. 3 ) and longer time to recurrence $(p=0.015)$. It is clear that these last two factors are of significance for pancreatic head cancers, but not for ampullary cancers (tables 1,2).

\section{Multivariate Analysis}

All factors that were significant in the univariate analysis were entered into a Cox regression model. Independent prognostic factors for survival for the pancreatic head group were: preoperative back pain and abdominal pain $\left(\mathrm{B}_{(\exp )}: 0.548 / \mathrm{p}=0.05\right)$ and differentiation grade (2.004/0.016). No independent prognostic factors were found for ampullary cancers.

For time to recurrence independent prognostic factors for the pancreatic head group were: preoperative back pain and abdominal pain $(0.446 / 0.015)$, positive lymph nodes (0.491/0.033), and EGF-R overexpression $(0.448 / 0.034)$. Independent prognostic factors for 
ampullary cancers were preoperative back pain and abdominal pain $(0.224 / 0.007)$ and perineural invasion $(0.199 / 0.031)$.

\section{Discussion}

Median survival and time to recurrence after R-0 resection were significantly longer for ampullary than for pancreatic head cancers. This evident difference may be due to earlier clinical presentation or different biological behavior. We found no differences in preoperative factors between both groups.

Preoperative back pain and abdominal pain was found in 51 patients (55\%). It was also an independent negative prognostic factor for time to recurrence for both groups and for survival in univariate analysis. We further found that intrapancreatic perineural invasion was a negative prognostic factor for survival (not for pancreatic head cancers, $p=0.273$ ) and time to recurrence in the univariate analysis (both groups). Preoperative pain as a negative prognostic factor has been reported earlier by Ridder and Klempnauer [23] and Okusaka et al. [24]. Forty-one percent of the patients with preoperative pain had intrapancreatic perineural growth, and $55 \%$ of the patients with perineural growth had preoperative pain. These findings suggest that pain is not always caused by intrapancreatic perineural growth and vice versa. Indeed, pain is usually interpreted as resulting from tumor infiltration into extrapancreatic (retropancreatic) splanchnic nerves and thus may indicate advanced tumor growth beyond the borders of the pancreas.

In the present study, $72 \%$ of all patients had recurrence of their cancer, and almost half of all recurrences were local (table 1). This is similar to previously reported rates in two large trials on adjuvant therapy done by Klinkenbijl et al. [3] and Neoptolemos et al. [25]. Although both studies included only $18-22 \% \mathrm{R}-1$ resections, the reported rate of recurrence was approximately $70 \%$, and $37-$ $52 \%$ of these recurrences were local.

Possibly our definition of R-0 resection may have included some 'irradical' resections. Verbeke et al. [26] suggested that R-1 resection can be underestimated, when the pathological examination is not completely standardized. These authors compared pathological examinations for two consecutive periods with and without a highly standardized protocol. The number of R-0 resections for pancreatic cancer during the standardized period was lower than during the nonstandardized period ( $\mathrm{p}=$ 0.009). Interestingly, long-term survival for pancreatic cancer was not predicted by resection status in either cohort. A similar observation was made by Neoptolemos et al. $[12,25]$ in a subanalysis of their trial on adjuvant therapy. They found that the resection status was not an independent prognostic factor for survival. Only after omission of nodal status and differentiation grade, the resection status became significant $[12,25]$.

It is intuitive that R-1 resection is a predictor of a poor survival, and indeed long-term survivors are sparse after $\mathrm{R}-1$ resection. Therefore, $\mathrm{R}-0$ resection is often considered to be the most important factor predicting a favorable outcome. Consequently, extended resections, including extensive clearing of retroperitoneal soft tissue and lymphatic tissue, have been advocated. Several randomized controlled trials [27-29] were performed, but failed to show a survival benefit for extended surgery. In a recent study performed by Hishinuma et al. [30], 27 patients who had undergone extended resection were studied at autopsy. Most resections were R-0 (25/27), 3 patients died postoperatively, the majority died of metastatic disease, and only 4 patients died due to local recurrence. Evidence of local recurrence was found in 18 of 24 patients (75\%) [30]. This study clearly shows that even after extended surgery, local recurrences are still frequent. Possibly R-0 and R-1 resections are both accompanied by (occult) metastatic disease. Indeed, in an overview of advanced molecular detection techniques [6], it was shown that tumor cells can be found pre- and perioperatively in peritoneal lavage fluids, liver, blood, 'tumor-negative' lymph nodes, and bone marrow of patients without 'conventional' evidence of metastatic disease. As a result, R-0 resection offers an opportunity for long-term survival for a limited number of patients. However, in the majority of the cases, resection cannot provide cure, and recurrence remains imminent. This further emphasizes the importance of additional prognostic parameters to predict outcomes after ' $R-0$ ' (' $R<$ 1') resection and to select patients in need of (aggressive) systemic adjuvant therapy.

The TMA technique proved to be a simple, efficient, and relatively inexpensive method to explore the protein expression in large groups of patients. Our failure rate of $3 \%$ is acceptable and did not cause statistical problems. The expression of p53 and p16 proteins is well known in pancreatic cancer [17]. Nevertheless, their prognostic value remains unclear. We found a similar expression of p16 (21-33\%) (table 1) to that reported in previous studies (13-59\%) [17]. The expression of p53 in our study was lower (19-20\%) than previously reported (35-69\%) [17]. This may be due to our techniques or a selection bias in our 
group (R-0). RB-1 protein expression has been reported previously in tissue and cell lines, the exact prevalence, however, was unclear $[31,32]$. We found RB-1 to be positive in $62-77 \%$ of the cases. C-myc, a proto-oncogene, expression has been previously reported [18]. We found improved survival for patients with overexpression of this protein. This is counterintuitive, since, as a known protooncogene, it is thought to promote oncogenesis and tumor growth. Alternatively, C-myc expression is thought to be an early step [18] in the rapid oncogenesis of pancreatic cancer [33] and may be an indicator of a relatively early point in tumor progression. Hypothetically, this implicates an early-stage disease and thus a less aggressive nature. Nevertheless, the exact role of C-myc remains unclear. We found $22 \%$ of the cancers to be positive for chromogranin $\mathrm{A}$, a neuroendocrine differentiation marker. This is similar to the previous report on neuroendocrine differentiation by Tezel et al. [34]. However, these authors did not find any chromogranin A-positive tumors in their specimens, in contrast to $18-36 \%$ expression of other neuroendocrine markers (NCAM, NSE, synaptophysin, CD57). This may be due to differences in antigen retrieval, immunohistochemical techniques, and/or antibody clones used. HER-2 was positive in only $9-11 \%$ of the cases and did not show a correlation with survival. This is comparable to previously published results (8-58\%) [17].
EGF-R, a well-known growth factor receptor, was positive in ampullary cancers (4\%), but significantly more often in pancreatic head cancers $(24 \%$; $p=0.026)$. This is in accordance with expression rates reported previously (2868\%) [17]. The difference in EGF-R expression between pancreatic head and ampullary cancers was previously suggested by Friess et al. [35]. Although their study did not provide matched clinical and survival data, they suggested a role for the EGF-R in the less favorable outcomes of pancreatic cancers. In our study, EGF-R overexpression was a negative prognostic factor for time to recurrence $(\mathrm{p}=$ 0.037 ) and possibly survival $(p=0.084)$. This effect on survival has been described previously in several studies, while others found no effect $[17,36]$. For head and neck cancer, the EGF-R expression was shown to be correlated with survival and relapse [37]. In breast and colorectal cancers, however, no correlation was evident [38, 39].

In conclusion, the differences in biological behavior between pancreatic head and ampullary cancers could be confirmed in this study. The poor prognosis of patients with pancreatic head cancer can possibly be related to the increased EGF-R expression of these tumors as compared with ampullary cancers. Our data support the rationale to use drugs that have recently been designed to target the EGF-R selectively (Tarceva, Iressa, Erbitux) [40] in adjuvant therapy regimens.

\section{References}

$>1$ Carpelan-Holmstrom M, Nordling S, Pukkala E, Sankila R, Luttges J, Kloppel G, Haglund $\mathrm{C}$ : Does anyone survive pancreatic ductal adenocarcinoma? A nationwide study re-evaluating the data of the Finnish Cancer Registry. Gut 2005;54:385-387.

$\checkmark 2$ Boyle P, Ferlay J: Cancer incidence and mortality in Europe, 2004. Ann Oncol 2005;16: 481-488.

>3 Klinkenbijl JH, Jeekel J, Sahmoud T, van Pel $\mathrm{R}$, Couvreur ML, Veenhof $\mathrm{CH}$, Arnaud JP, Gonzalez DG, de Wit LT, Hennipman A, Wils J: Adjuvant radiotherapy and 5-fluorouracil after curative resection of cancer of the pancreas and periampullary region: phase III trial of the EORTC gastrointestinal tract cancer cooperative group. Ann Surg 1999;230:776-782; discussion 782-774

4 van Oost FJ, Luiten EJ, van de Poll-Franse LV, Coebergh JW, van den Eijnden-van Raaij AJ: Outcome of surgical treatment of pancreatic, peri-ampullary and ampullary cancer diagnosed in the south of The Netherlands: a cancer registry based study. Eur J Surg Oncol 2006;32:548-552
-5 Stocken DD, Büchler MW, Dervenis C, Bassi C, Jeekel H, Klinkenbijl JH, Bakkevold KE, Takada T, Amano H, Neoptolemos JP: Metaanalysis of randomised adjuvant therapy trials for pancreatic cancer. Br J Cancer 2005; 92:1372-1381.

6 Vogel I, Kalthoff H, Henne-Bruns D, Kremer B: Detection and prognostic impact of disseminated tumor cells in pancreatic carcinoma. Pancreatology 2002;2:79-88.

-7 Baumel H, Huguier M, Manderscheid JC, Fabre JM, Houry S, Fagot H: Results of resection for cancer of the exocrine pancreas: a study from the French Association of Surgery. Br J Surg 1994;81:102-107.

$>8$ Willett CG, Lewandrowski K, Warshaw AL, Efird J, Compton CC: Resection margins in carcinoma of the head of the pancreas. Implications for radiation therapy. Ann Surg 1993;217:144-148.

$\checkmark 9$ Appelqvist P, Viren M, Minkkinen J, Kajanti M, Kostiainen S, Rissanen P: Operative finding, treatment, and prognosis of carcinoma of the pancreas: an analysis of 267 cases. J Surg Oncol 1983;23:143-150.
10 Geer RJ, Brennan MF: Prognostic indicators for survival after resection of pancreatic adenocarcinoma. Am J Surg 1993;165:68-72; discussion 72-73.

11 Nix GA, Dubbelman C, Wilson JH, Schutte HE, Jeekel J, Postema RR: Prognostic implications of tumor diameter in carcinoma of the head of the pancreas. Cancer 1991;67: 529-535.

12 Neoptolemos JP, Stocken DD, Dunn JA, Almond J, Beger HG, Pederzoli P, Bassi C, Dervenis C, Fernandez-Cruz L, Lacaine F, Buckels J, Deakin M, Adab FA, Sutton R, Imrie C, Ihse I, Tihanyi T, Olah A, Pedrazzoli S, Spooner D, Kerr DJ, Friess H, Büchler MW: Influence of resection margins on survival for patients with pancreatic cancer treated by adjuvant chemoradiation and/or chemotherapy in the ESPAC-1 randomized controlled trial. Ann Surg 2001;234:758-768.

13 Kononen J, Bubendorf L, Kallioniemi A, Barlund M, Schraml P, Leighton S, Torhorst J, Mihatsch MJ, Sauter G, Kallioniemi OP: Tissue microarrays for high-throughput molecular profiling of tumor specimens. Nat Med 1998;4:844-847. 
-14 Swierczynski SL, Maitra A, Abraham SC, Iacobuzio-Donahue CA, Ashfaq R, Cameron JL, Schulick RD, Yeo CJ, Rahman A, Hinkle DA, Hruban RH, Argani P: Analysis of novel tumor markers in pancreatic and biliary carcinomas using tissue microarrays. Hum Pathol 2004;35:357-366.

15 Ezhevsky SA, Nagahara H, Vocero-Akbani AM, Gius DR, Wei MC, Dowdy SF: Hypophosphorylation of the retinoblastoma protein $(\mathrm{pRb})$ by cyclin $\mathrm{D}: \mathrm{Cdk} 4 / 6$ complexes results in active pRb. Proc Natl Acad Sci USA 1997;94:10699-10704.

-16 Medema RH, Herrera RE, Lam F, Weinberg RA: Growth suppression by p16ink 4 requires functional retinoblastoma protein. Proc Natl Acad Sci USA 1995;92:6289-6293.

17 Garcea G, Neal CP, Pattenden CJ, Steward WP, Berry DP: Molecular prognostic markers in pancreatic cancer: a systematic review. Eur J Cancer 2005;41:2213-2236.

18 Schleger C, Verbeke C, Hildenbrand R, Zentgraf H, Bleyl U: c-MYC activation in primary and metastatic ductal adenocarcinoma of the pancreas: incidence, mechanisms, and clinical significance. Mod Pathol 2002;15: 462-469.

-19 Büchler P, Reber HA, Eibl G, Roth MA, Büchler MW, Friess H, Isacoff WH, Hines OJ: Combination therapy for advanced pancreatic cancer using Herceptin plus chemotherapy. Int J Oncol 2005;27:1125-1130.

20 Li J, Kleeff J, Giese N, Büchler MW, Korc M, Friess H: Gefitinib ('Iressa', ZD1839), a selective epidermal growth factor receptor tyrosine kinase inhibitor, inhibits pancreatic cancer cell growth, invasion, and colony formation. Int J Oncol 2004;25:203-210.

-21 Rozenblum E, Schutte M, Goggins M, Hahn SA, Panzer S, Zahurak M, Goodman SN, Sohn TA, Hruban RH, Yeo CJ, Kern SE: Tumor-suppressive pathways in pancreatic carcinoma. Cancer Res 1997;57:1731-1734.

22 Sobin LH, Wittekind C (eds): TNM Classification of Malignant Tumors, ed 6. New York, Wiley, 2002.
23 Ridder GJ, Klempnauer J: Back pain in patients with ductal pancreatic cancer: its impact on resectability and prognosis after resection. Scand J Gastroenterol 1995;30: 1216-1220.

24 Okusaka T, Okada S, Ueno H, Ikeda M, Shimada K, Yamamoto J, Kosuge T, Yamasaki S, Fukushima N, Sakamoto M: Abdominal pain in patients with resectable pancreatic cancer with reference to clinicopathologic findings. Pancreas 2001;22:279-284.

25 Neoptolemos JP, Stocken DD, Friess H, Bassi C, Dunn JA, Hickey H, Beger H, FernandezCruz L, Dervenis C, Lacaine F, Falconi M, Pederzoli P, Pap A, Spooner D, Kerr DJ, Büchler MW: A randomized trial of chemoradiotherapy and chemotherapy after resection of pancreatic cancer. N Engl J Med 2004; 350:1200-1210.

26 Verbeke CS, Leitch D, Menon KV, McMahon MJ, Guillou PJ, Anthoney A: Redefining the $\mathrm{R} 1$ resection in pancreatic cancer. Br J Surg 2006;93:1232-1237.

27 Farnell MB, Pearson RK, Sarr MG, DiMagno EP, Burgart LJ, Dahl TR, Foster N, Sargent DJ: A prospective randomized trial comparing standard pancreatoduodenectomy with pancreatoduodenectomy with extended lymphadenectomy in resectable pancreatic head adenocarcinoma. Surgery 2005;138 618-628; discussion 628-630.

28 Yeo CJ, Cameron JL, Lillemoe KD, Sohn TA, Campbell KA, Sauter PK, Coleman J, Abrams RA, Hruban RH: Pancreaticoduodenectomy with or without distal gastrectomy and extended retroperitoneal lymphadenectomy for periampullary adenocarcinoma. 2. Randomized controlled trial evaluating survival, morbidity, and mortality. Ann Surg 2002; 236:355-366; discussion 366-368.

29 Pedrazzoli S, DiCarlo V, Dionigi R, Mosca F, Pederzoli P, Pasquali C, Kloppel G, Dhaene K, Michelassi F: Standard versus extended lymphadenectomy associated with pancreatoduodenectomy in the surgical treatment of adenocarcinoma of the head of the pancreas: a multicenter, prospective, randomized study. Lymphadenectomy Study Group. Ann Surg 1998;228:508-517.

-30 Hishinuma S, Ogata Y, Tomikawa M, Ozawa I, Hirabayashi K, Igarashi S: Patterns of recurrence after curative resection of pancreatic cancer, based on autopsy findings. J Gastrointest Surg 2006;10:511-518.
31 Ruggeri B, Zhang SY, Caamano J, DiRado M, Flynn SD, Klein-Szanto AJ: Human pancreatic carcinomas and cell lines reveal frequent and multiple alterations in the p53 and Rb-1 tumor-suppressor genes. Oncogene 1992;7: 1503-1511.

32 Howe JR, Conlon KC: The molecular genetics of pancreatic cancer. Surg Oncol 1997;6: $1-18$.

33 Real FX: A 'catastrophic hypothesis' for pancreas cancer progression. Gastroenterology 2003;124:1958-1964.

34 Tezel E, Nagasaka T, Nomoto S, Sugimoto H, Nakao A: Neuroendocrine-like differentiation in patients with pancreatic carcinoma. Cancer 2000;89:2230-2236.

35 Friess H, Wang L, Zhu Z, Gerber R, Schröder M, Fukuda A, Zimmermann A, Korc M, Büchler MW: Growth factor receptors are differentially expressed in cancers of the papilla of Vater and pancreas. Ann Surg 1999; 230:767-774; discussion 774-775.

36 Bloomston M, Bhardwaj A, Ellison EC, Frankel WL: Epidermal growth factor receptor expression in pancreatic carcinoma using tissue microarray technique. Dig Surg 2006; 23:74-79.

37 Ang KK, Berkey BA, Tu X, Zhang HZ, Katz R, Hammond EH, Fu KK, Milas L: Impact of epidermal growth factor receptor expression on survival and pattern of relapse in patients with advanced head and neck carcinoma. Cancer Res 2002;62:7350-7356.

38 Spano JP, Lagorce C, Atlan D, Milano G, Domont J, Benamouzig R, Attar A, Benichou J, Martin A, Morere JF, Raphael M, PenaultLlorca F, Breau JL, Fagard R, Khayat D, Wind P: Impact of EGFR expression on colorectal cancer patient prognosis and survival. Ann Oncol 2005; 16:102-108.

39 Chan SK, Hill ME, Gullick WJ: The role of the epidermal growth factor receptor in breast cancer. J Mammary Gland Biol Neoplasia 2006;11:3-11.

40 Blackledge G, Averbuch S: Gefitinib ('Iressa', ZD1839) and new epidermal growth factor receptor inhibitors. Br J Cancer 2004;90: 566-572. 